\title{
Learning Maths The Fun Way With Magic Maths
}

Selvaraju a/l Munandy

Pertubuhan Magik Matematik, 426, Lorong Seri Petaling 2/5, Taman Seri Petaling, 09000 Kulim, Kedah

*Corresponding author: selvaraju@mathsmagics.org

\begin{abstract}
Mathemagics or 'Magic Maths' consists of a series of non-conventional maths formulas that turn Mathematics into a fun subject and create innovative minds. The magical system could help steer the country towards a knowledge economy. The magic formulas, based on Ancient Indian Scriptures, were in use by the United States National Aeronautics and Space Administration (NASA), Intel Corporation, Microsoft, IBM and India, for its competitive exams preparations. The high speed mental mathematics could speed up math calculation by up to $1500 \%$ and turn students into human bio-calculators. Mathemagics presents varieties of methods which can be used according to one's needs in solving even the most difficult math problems. This is unlike the conventional system consisting of rigid, sometimes monotonous, procedures that are uniformly applied to all problems of a given type. The conventional method of calculation was not user - friendly with hardly any room for choice and experimentation. A seemingly difficult calculation like 998 x 997 can be solved in less than five seconds and even mentally. There is also a unique method to check the accuracy of answers to addition, subtraction, multiplication and division, in keeping with the basic needs of students for faster calculations with $100 \%$ accuracy. Innovation of the formula would make students become more confident and gain self - esteem while cultivating an interest for numbers and help eliminate math - phobia in them. The system also opens a new horizon for mathematics lovers as it presents a wider platform for experimentation in the subject. Besides, it promotes development of the right brain which governs the ability to solve complex calculations that require the use of visualization, photographic memory, speed reading and sub-conscious learning together with the left - brain that is employed by students for $90 \%$ of subjects taught at school.
\end{abstract}

Keywords: Magic; mathematics; conventional; phobia; rigid; monotonous; fun; easy; speed; accuracy; aphorisms

(C) 2017 Penerbit UTM Press. All rights reserved

\subsection{MATHEMATICS MADE FUN AND EASY}

Today about $50 \%$ of students who obtained Grade 'A' and 'B' at primary level, $50 \%$ of them ended up in arts stream finding secondary mathematics is difficult. In another side, from the remaining $50 \%$ of students who obtained Grade ' $\mathrm{C}$ ', ' $\mathrm{D}$ ' and ' $\mathrm{E}$ ', $80 \%$ of them lost the total interest to learn mathematics at secondary level. The enrolment in the science stream is still at worrying level as to the date, only $42 \%$ than the expected $60 \%$ in most of the schools.

The main cause of students suffers from mathematics phobia is because mathematics is so perfect. $2+2$ has to be 4 and not 5 and 6 . The second reason because of the long calculations involved through the conventional system which was not user-friendly with hardly any room for choice and experimentation. The conventional methods of mathematical computations consist of rigid, sometimes monotonous procedures that are uniformly applied to all problems of a given time. As it's only one -side of brain education; left-brain which is known as 'logic brain', it lacks creativity and the result is often boredom, strain and lack of enjoyment for both students and teachers.

By contrast to the conventional mathematics system, Magic Maths promotes fun learning by introducing a series of non-conventional formulas that converts a tedious subject: Mathematics into a playful and blissful one in which learners learn with smiles. Magic maths is based on aphorisms which are refined formulas for producing a high degree of coherence and in order in brain functioning, facilitating the rapid and precise solution to the mathematical problem. This is easily the World's Fastest Mental Calculations System which has its roots in Ancient Indian Scriptures. With the system, not only be able to add, subtract, multiply or divide which is the limiting factor of the abacus, but also be able to solve complex mathematics such as algebra, geometry, calculus and trigonometry. Some of the most advanced, complex and arduous problems can be solved using the Magic Maths with extreme ease.

Magic Maths is far more systematic, simplified and unified than conventional system. For an example, the confidence in the learners can be built in seconds through solving a very complex calculation creatively such as $998 \times 997$ in less than 5 seconds mentally, even without knowing the multiplication of 9 at all. It is a mental tool for calculation that encourages the development and use of intuition and innovation, while giving the students a lot of flexibility, fun and satisfaction. For learners, it means giving them a competitive edge, a way to optimize their performance and gives them an edge in mathematics and logic that will help them to shine in the classroom and beyond. The flexibility in the method keeps the mind lively and alert and cultures the ability to quickly discover the path of least action on the way to the solution.

Once the right brain is developed through the aphorisms, learning then becomes automatic. In brain, the nerve cells, which are used to function, become sensitive suddenly. Swift information flow stimulates the nerve cells connected to the visual and auditory centers in the brain and brings about chain reactions between each and every nerve cells one after another. This process activates the entire brain which then can attain its full potential. 
Magic Maths brings the students in a comfortable zone as far as mathematical calculation is concerned. It presents varieties of methods which one can use according to one's need and the students can come out of the confinement of the only - one correct way, and make their own methods under Magic Maths. By creating abilities of solving complex calculations mentally which is a right brain education, it empowered the both brains and develop photographic memory skills automatically. This will be helpful in learning other subjects which needs memorization skills while cultivating an interest for numbers and eliminates the maths-phobia present in the students. It also trigger a speed in reading which is helpful to the students where can do more reading in a short time. These powerful skills; photographic memory and speed reading is leading to a great sub-conscious learning which the students will truly enjoy studies all the time and lead to the successful life.

\subsection{OUTPUT OF MAGIC MATHS}

Mathematics is called the queen of all subjects but it is considered an insipid subject and disliked by many students and adults due to its nature of long calculations, Magic Maths brings the students in a comfortable zone as far as mathematical calculation is concerned. The ability to perform basic mathematical calculations mentally is an art and brings revolutionary change in the mind of learners who find mathematics as an insipid subject. The main reason behind mathematics phobia is lengthy calculation. The traditional method of calculation is not user - friendly and there is hardly any room for choice and experimentation. Addition, Subtraction, Multiplication, Division, Square, Square Root, Cube, Cube Root are the basic structure of mathematics. Magic Maths presents varieties of methods which one can use according to one's need. Not only that, it has two more feathers in its cap: one is casting out nines, a unique and special method to check the accuracy Addition, Subtraction, Multiplication and Division in a few seconds and the second special feature is the topic on solving simple equations. Magic Maths keeping in view the basic needs of the present - day student who wants faster calculation technique with $100 \%$ accuracy.

Magic Maths has the prowess to speed up Maths calculations by up to $1500 \%$ and supposedly seemingly difficult calculations like 998 x 997 can be solved in less than 5 seconds flat. With this system, the students will become a Human Bio - Calculator. As the students start to learn mathematics via innovative methods which have been found easier to learn, the students will suddenly become more confident with energy and high self - esteem. The innovative methods also will cultivate an interest for numbers and eliminates the maths - phobia present in the students.

Magic Maths opens a new horizon for the mathematics lover. It presents the wider platform to experiment with simple presentation. Even the common man who is not much interested in mathematics and suffers from Mathematical phobia can find the presentation of Magic Maths interesting as the speed of Magic Maths is $10-15$ times faster than normal maths. It helps to carry out tedious and cumbersome arithmetical operations mentally, while sharpens your mind, increases mental agility.

The examples shown below demonstrate some applications of the Magic Maths:-

\begin{tabular}{|c|c|}
\hline \multicolumn{2}{|c|}{$142 \div 9=?$} \\
\hline Conventional Method & Magic Math Method \\
\hline 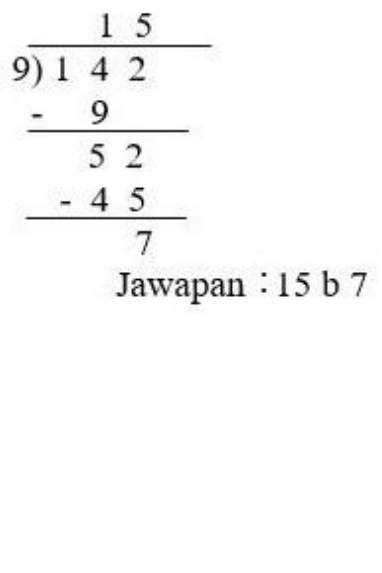 & $\begin{array}{l}\text { Jawapan }: 15 \text { b } 7 \\
\text { Step } 1: \text { Bring down as the first answer } \\
\text { Step 2: Add } 1 \text { to neighbor, } 1+4=5 \text {, bring } \\
\text { down } 5 \text { as the next answer. Then } \\
\text { repeat the pattern. } \\
\text { Step } 3 \text { : Place a reminder before the last } \\
\text { added digits }\end{array}$ \\
\hline
\end{tabular}

Figure 1 Illustrative example of Magic Maths method of solving division problem without the use of table and by simple addition. 


\begin{tabular}{|c|c|}
\hline \multicolumn{2}{|c|}{$1326 \times 11=$ ? } \\
\hline Conventional Method & Magic Math Method \\
\hline $\begin{array}{r}1326 \\
\times \quad 11 \\
1326 \\
1326 \\
14586\end{array}$ & $\begin{array}{l}\text { Step } 1: \text { Bring down the first digit, } 1 \text { down } \\
\text { Step } 2: \text { Add } 1 \text { to } 3=4 \text {, bring down } 4 \\
\text { Step } 3: \text { Add } 3 \text { to } 2=5 \text {, bring down } 5 \text {, } \\
\text { repeat till the last digit. } \\
\text { Step } 4: \text { Bring down the last digit, } 6 \text { down }\end{array}$ \\
\hline
\end{tabular}

Figure 2 Illustrative example of Magic Maths method of solving multiplication problem without the use of table and by a simple pattern

\begin{tabular}{|c|c|}
\hline \multicolumn{2}{|c|}{$55203-16545=?$} \\
\hline Conventional Method & Magic Math Method \\
\hline $\begin{array}{r}55203 \\
-16545 \\
38658\end{array}$ & 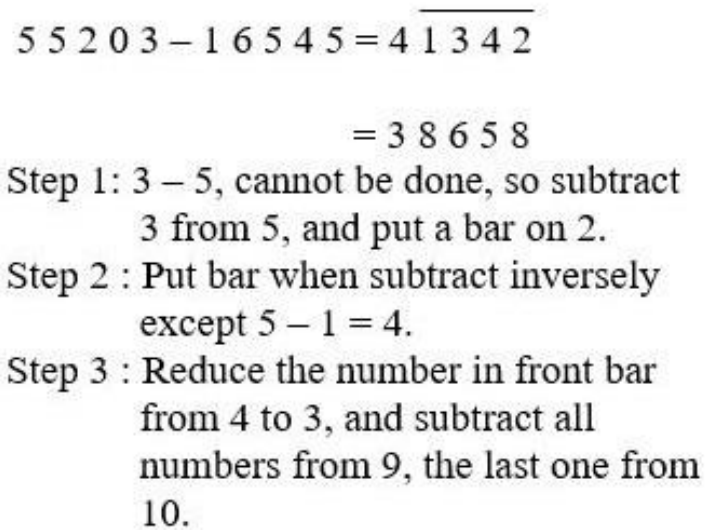 \\
\hline
\end{tabular}

Figure 3 Illustrative example of Magic Maths method of solving subtraction in just 2 lines without using the current conventional 'borrow' method

Figure 1,2 and 3 demonstrates Magic Maths formulas for primary school, while Magic Maths also has developed formulas for secondary level such as; Genius algebra, Genius Square, etc and also for university students: Genius polynomials and many more. Here are some of the benefits of using Magic Maths formulas in teaching and learning:-

a. "allow for self expression, encouraging student's own response."

b. "encourage students to participate verbally through speed test and speed quiz activities."

c. "provide relaxation (a legitimate opportunity to wiggle and move around)."

d. "assists the students in learning to follow directions."

e. "increase attention span."

f. "develops listening skills."

g. "encourage students to think out of box and ask questions."

h. "inspire the students to experiment with magic formulas."

\section{Fun Learning}

Fun learning is simply engaging students to solve arithmetics problems using new and easy patterns through written and verbal test. After learning each of the formulas, the students will be guided to answer mentally through quizzes. By doing this, the students will participate in the class actively and develop a huge self - esteem instantly. Most of them will be very excited to answer and this will create fun environment. After the section of Magic Maths, the students concentrate well into the conventional method and they developed a fast understanding on 
the syllabus. After about 3 months, a competition called 'Speed Test' and 'Speed Quiz' arranged in order to inspire amongst them to perform the best. To date, a total of 4500 students have attended the Magic Maths training and about $90 \%$ of the students converted into maths-lover from maths-phobia.

\section{Acknowledgements}

Sincere gratitude goes to my Guru who has given me the inspiration to share this noble idea and formulas that can be used to build self esteem which will help students to transform, and lead a happy and fulfilling life.

I would like to thank my late mother, my wife for their support and encouragement towards this idea. Special appreciation and thanks goes to my dear advisors, Dr.Rajendran a/l Muthuveloo(USM), Dr.Syed Shahar Syed Ahmad Barakbah(AIU), Tan Sri Dr. M. Thambirajah, Dr. Faridah bt. Abu Hassan (Pengarah BPPDP, KPM), Mr. L.Krishnan for their encouragement and support provided throughout the process of development and sharing the vision of Magic Maths Organization.

I would like to express my gratitude to the many people who saw me through this idea and beg forgiveness for all those who have been with me over the course of the years and whose names I have failed to mention. Last but not least, I would like to express my appreciation to the organizers of National Maths - Science Simposium 2015 for providing me the wonderful opportunity to present my ideas on Magic Maths.

\section{References}

Jagadguru Sankaracarya Sri Bharati Krsna Tirthaji Maharaja (1992). Vedic Mathematics, New Delhi: Motilal Banarsidass Publishers (P) Ltd, $45-47$.

Kenneth R Williams (2002). Vedic Mathematics (Elementary Level), New Delhi: Motilal Banarsidass Publishers (P) Ltd, $92-94$.

Kenneth R Williams (2006). Discover Vedic Mathematics, New Delhi: Motilal Banarsidass Publishers (P) Ltd, 12-13.

Kenneth R Williams (2002). Vedic Mathematics (Advanced Level), New Delhi: Motilal Banarsidass Publishers (P) Ltd, 29-30.

Dhaval Bathia, (2008) Vedic Mathematics Made Easy, Mumbai: Jaico Publishing House, 25-27.

Rajendran Muthuveloo,(2013). Rats to Star, Malaysia, Rajendran a/l Muthuveloo, 70-71 